\title{
O SENSOWNOŚCI UCZUĆ. DZIEDZICTWO MYŚLI EDYTY STEIN
}

\begin{abstract}
Streszczenie. Koncepcja Edyty Stein rozumienia drugiego człowieka jest znana z jej dysertacji O zagadnieniu wczucia. Niemniej, gruntowne przebadanie struktury osobowości ludzkiej, jakie podjęła w Filozofii psychologii i humanistyki, rzuca nowe światło na tę kwestię. Stein dokonuje swoistej syntezy Husserlowskiego prymatu prawdy i Schelerowskiej koncepcji miłości, unikając przy tym idealizmu i woluntaryzmu, którym obarczone są te stanowiska. Steinowska koncepcja znajduje kontynuację w fenomenologii Merleau-Ponty'ego i R. Barbarasa.
\end{abstract}

Słowa kluczowe: fenomenologia, antropologia, uczucia, wczucie, wartości, E. Stein, F. Brentano, E. Husserl, M. Scheler

1. Wprowadzenie. 2. Uczucia i intencjonalność: F. Brentano, E. Husserl, M. Scheler. 3. Sfera emocjonalna. „Osobowość” według Stein. 4. W stronę sensu tożsamości indywidualnej.

5. Zakończenie.

\section{WPROWADZENIE}

Steinowska koncepcja rozumienia uczuć wyrasta na przecięciu osiągnięć fenomenologicznych E. Husserla i M. Schelera. Jest zwykle identyfikowana $z$ teorią wczucia (empathy), za sprawą rozpowszechnionego tłumaczenia dysertacji $O$ zagadnieniu wczucia. Nie wydaje się to jednak uzasadnione. Przedstawia się ona jako swoista synteza Husserlowskiego prymatu prawdy i Schelerowskiej koncepcji miłości, unikając przy tym idealizmu i woluntaryzmu, którym obarczone są te stanowiska. Steinowska koncepcja znajduje kontynuację w fenomenologii Merleau-Ponty'ego i R. Barbarasa. Prezentując zagadnienie rozumienia uczuć w szerszych ramach, obejmujących intencjonalność, doświadczenie źródłowe, problematykę osobowości i tożsamości indywidualnej, a także świat wartości jako szeroko 
pojętą kulturę, argumentuję za dynamiczną, procesualną koncepcją rozumienia uczuć, „umiejętnością wyczucia tego, co lepsze”, czyli swoistą diapatiq.

\section{UCZUCIA I INTENCJONALNOŚĆ: F. BRENTANO, E. HUSSERL, M. SCHELER}

Zagadnienie intencjonalności uczuć odsyła do Brentanowskiej wykładni idei Kartezjańskich. W pracy Psychologia z empirycznego punktu widzenia Franz Brentano wysuwa tezę o trzech głównych klasach czynności psychicznych u Kartezjusza, a mianowicie o klasie „przedstawień” (Vorstellungen), klasie sądów oraz klasie przeżyć emocjonalnych, zainteresowania lub miłości ${ }^{1}$. Należy przy tym zaznaczyć, że klasa tak zwanych „przedstawień” z powodu „pewnej luki terminologicznej” jest rozumiana w tym przypadku „w najogólniejszym sensie”. Brentano wyjaśnia: „Kiedy coś widzimy, przedstawiamy sobie pewną barwę, kiedy coś słyszymy - pewien dźwięk, kiedy coś sobie wyobrażamy - pewien twór wyobraźni. Dzięki ogólności, z jaką używamy tego słowa, mogliśmy powiedzieć, że jest wykluczone, aby czynność psychiczna w jakikolwiek sposób odnosiła się do czegoś, co nie jest przedstawione”3. Brentano, pisząc o tym, że są to fenomeny psychiczne, nie stawia znaku równości między „przedstawieniem” a „reprezentacją” (Darstellung). Wyjaśnia on tę kwestię w polemice, a mianowicie: „W tym sensie, w którym my używamy słowa "przedstawiać", być "przedstawianym" znaczy tyle, co: pojawiać się (erscheinen)"4. Nie chodzi też o to, co jest przedstawiane, lecz „sam akt przedstawiania sobie”5. A zatem do przykładów fenomenów

1 Por. F. Brentano, Psychologia z empirycznego punktu widzenia, tłum. z niem. W. Galewicz, Warszawa 1999, 290.

2 Tamże, 291, przyp. 3.

3 Tamże, 291.

4 Tamże, 116.

5 Tamże, 113. 
psychicznych tej klasy zalicza on: „słyszenie pewnego dźwięku, widzenie barwnego przedmiotu, odczuwanie ciepła lub zimna jak też podobne stany wyobrażeniowe"6. Odczytuje on więc myśl Kartezjusza przez pryzmat cogitationes.

Zjawiska psychiczne, zdaniem Brentany, wyróżniają się intencjonalnością, czyli „odniesieniem do pewnej treści, skierowaniem na pewien obiekt (...) lub immanentną przedmiotowością"7. Problem psychologizmu uwyraźnił konieczność dalszych badań w tej kwestii. Poszły one w co najmniej dwóch kierunkach. Zasługą Kazimierza Twardowskiego, twórcy szkoły lwowsko-warszawskiej, ucznia Brentany, było uzyskanie zasadniczego rozróżnienia „pomiędzy aktem, treścią i przedmiotem"8 oraz - jak podkreśla Ryszard Kleszcz - wypracowanie podstaw dla nauk humanistycznych w kolejnej przełomowej pracy $O$ czynnościach $i$ wytworach ${ }^{9}$. Inny kierunek obrał Husserl. Edyta Stein wyjaśnia: „Rozgraniczenie fenomenologii i psychologii, dokonane przez Husserla w Ideach czy już wcześniej w jego artykule Philosophie als strenge Wissenschaft na łamach Logosu, polega (...) na tym niezbędnym oddzieleniu świadomości od psychiczności"10. Sam Husserl swój program badawczy zakreśla w słowach: „Radykalny postęp był właściwie $\mathrm{w}$ ogóle niemożliwy przed wprowadzeniem systematycznej fenomenologii świadomości. Niewyjaśnione fenomenologicznie pojęcia, jak »akt«, »treśč " "przedmiot przedstawień«- nic nam nie pomogą. Czegoż to nie może znaczyć akt i czego zarazem treść pewnego przedstawienia i samo przedstawienie. I należy naukowo poznać samo to, co tak może się nazywać"11.

6 Tamże.

7 Tamże, 126.

8 E. Husserl, Idee czystej fenomenologii i fenomenologicznej filozofii, ks. 1, tłum. z niem. D. Gierulanka, Warszawa 19752, 422.

9 Por. P. Janik, „Czynności i wytwory” w perspektywie fenomenologicznej, Filo-Sofija 40(2018)1, 151.

10 E. Stein, Filozofia psychologii i humanistyki, tłum. z niem. P. Janik, M. Baran, J. Gaca, Kraków 2016, 105.

11 E. Husserl, dz. cyt., 423. 
Obok intencjonalności, kluczowym zagadnieniem jest rozumienie doświadczenia źródłowego. Husserl posługiwał się terminem „cielesna samo-obecność" (leibliche Selbstgegebenheit, Selbstgegegenwart), przy czym oznacza ona wyanalizowanie pojęć, to znaczy wgląd lub ogląd eidetyczny. Chodzi o to, by nie przyjmować za oczywiste samo przez się niczego, co nie jest bezpośrednio dane w doświadczeniu ani też nie posługiwać się wynikami innych nauk czy teorii. Oznacza również powrót do rzeczy samych, jak głosi hasło fenomenologii. Niemniej, intencjonalność powiązana ze źródłowością doświadczenia, została utożsamiana przez Husserla z percepcją.

Ponieważ Husserl nie „zagospodarował” wszystkich rodzajów czynności psychicznych wyróżnionych przez Brentanę, Max Scheler wysunął koncepcję „intencjonalności” w ramach „logiki serca”. Podkreślić należy jednak, że fenomenologia Schelera nie ma korzeni Brentanowskich. Pozostaje ona pod wpływem ustaleń Immanuela Kanta, z którego poglądami Brentano polemizował, co szczególnie jest widoczne przez wykluczenie ze sfery „poruszeń serca” (Gemuet) uczuć i afektów ${ }^{12}$ oraz przez uznanie kognitywnej zdolności „serca” (Gemuet) jako umysłu13.

Różnica stanowisk między Schelerem a Brentaną jest też widoczna w kwestii wartości. Brentano pisze, że dla Arystotelesa „dobry” i „godny pożądania” są wyrażeniami równoznacznymi, dlatego „utożsamia on przyczynę celową z dobrem” ${ }^{14}$. Również Tomasz z Akwinu, jak podkreśla Brentano, utrzymywał, że ,jak poznanie odnosi się do jakiegoś przedmiotu jako poznawalnego, tak pożądanie odnosi się do niego jako dobrego"15. Poglądy Arystotelesa i Akwinaty wyraził na nowy sposób Rudolf H. Lotze, pisząc o ,uczuciach ujmu-

12 Por. M. Scheler, Istota i formy sympatii, tłum. z niem. A. Węgrzecki, Warszawa 1980, 223. Brentano uczucia i wolę ujmuje w ramach tej samej klasy, por. F. Brentano, dz. cyt., 341-348.

13 Por. F. Brentano, dz. cyt., 292, przyp. 4.

14 Por. tamże, 350.

15 Tamże. 
jących wartości”16. Jednak, dodaje Brentano, „w jaki sposób Lotze rozumie ujmowanie wartości w uczuciu, tego nie odważyłbym się kategorycznie twierdzić"17. Scheler wprowadza szereg modyfikacji w powyższe ustalenia. Przede wszystkim, „przedmiot, ku któremu w fenomenie zwraca się miłość, nie musi być intencjonalnie ten sam, co przedmiot współodczuwania [uczucia - P.J.]”. Według Schelera bowiem, „miłość nie jest »czuciem» (...), lecz »aktem« i »ruchem»"18. Ponadto, „wszelkie czucie jest przyswajaniem (...) określamy to jako »funkcję«. Miłość natomiast jest poruszeniem serca (Gemuet) i aktem duchowym"19. Scheler ma w tym względzie szczególne rozumienie „miłości”. Pisze on, że „wprawdzie miłość jest ruchem ku pozytywnej wartości, ale to, czy owa wartość już istnieje, czy nie, jest dla miłości, z punktu widzenia jej istoty, obojętne" 20 . Scheler chce przez to powiedzieć, że „w miłości nie występuje” dążenie do „zrealizowania jakiejś treści”21. „Treścią” tą byłoby rzecz jasna określone, konkretne dobro w postaci jakości zmysłowych. Kryterium celowości dążenia, ma więc podkreślać nietożsamość pożądania i miłości. Innymi słowy, ma wyrażać pozytywnie to, że miłość jest z natury „bezinteresowna”. Scheler czasem posługuje się więc metaforą, bez sygnalizowania tego faktu.

Trzeba też pamiętać, że Scheler przeciwstawia się Kantowskiemu formalizmowi, wysuwając postulat „materialnych”22 wartości jako dóbr, oraz określa hierarchię wartości jako „meta-porządek warstw

\footnotetext{
16 Tamże, 351.

17 Tamże, 352.

18 M. Scheler, Istota i formy sympatii, dz. cyt., 223.

19 Tamże.

20 Tamże, 221.

21 Tamże.
}

22 Mówiąc o „wartościach materialnych”, na przykład dobru, Scheler używa terminu „materialny” w sensie fenomenu dostępnego przez czucie, który umożliwia uchwycenie wartości, nie zaś w sensie materiału, z którego jest „rzecz materialna”. Por. M. Scheler, Der Formalismus in der Ethik und die materiale Wertethik: neuer Versuch der Grundlegung eines ethischen Personalismus, red. M.S. Frings, Bonn 2009, 43 oraz 45. 
różnego rodzaju dóbr"23, a mianowicie dostępnych przez czucie $(F u-$ eblen) wartości: 1) przyjemnych dla zmysłów (sinnlichen), 2) witalnych (vitalen), 3) osobowych (geistigen), oraz 4) „sacrum i profanum” (Heiligen). Zdaniem Schelera, tylko wartości „sacrum i profanum” są absolutne, pozostałe wartości są natomiast ich symbolami ${ }^{24}$.

Scheler, odróżniając intencjonalność uczuć od intencjonalności miłości, analizuje przypadki „fałszywego współczucia”, kiedy współczuje się „,bez miłości do tego, komu się współczuje” 25 . „Współczucie” jest wówczas dodatkowym ciężarem, budząc „świadomość »urażonej dumy«, "wstydu«, "poniżenia«"26. Innym przypadkiem jest z kolei ten, „gdy nienawidzimy, cieszymy się z bólu i uszczerbku; ujawnia się wtedy szereg (...) negatywnie wartościowych uczuć: zazdrość, radość z czyjegoś niepowodzenia"27. Wydaje się więc, że Scheler postuluje „niezależność" uczuć od osoby, jeśli rozumieć przez nią poruszenia serca lub akt duchowy ${ }^{28}$.

\section{SFERA EMOCJONALNA. „OSOBOWOŚĆ” WEDŁUG STEIN}

Teoria wartości Stein jest swoistą syntezą pozycji Husserla i Schelera, jak zauważa Mette Lebech ${ }^{29}$. Stein rozumie ,intencjonalność” według funkcjonalnej wykładni Husserla. Przy czym, opiera swoją teorię ludzkiej osobowości na intencji30. Intencja (Absicht) w przeciwieństwie do wglądu (Einsicht) jest zdaniem Stein aktem własnym par excellence, a zatem aktem osobowym. Podziela ona w tym względzie

23 Por. tamże, 122-126.

24 Por. tamże, 126.

25 M. Scheler, Istota i formy sympatii, dz. cyt., 225.

26 Tamże, 225.

27 Tamże.

28 Zarzut ten wysunie M. Heidegger. Por. M. Heidegger, Bycie i czas, tłum. z niem. B. Baran, Warszawa 1994, 67.

29 M. Lebech, „Edith Stein's Phenomenological Value Theory”, Yearbook of the Irish Philosophical Society 2010 (2010), 139.

30 Por. E. Stein, dz. cyt., 143. 
zatem ogólne stanowisko Schelera. Ponieważ intencja dotyczy sfery emocjonalnej, jej przedmiotem jest świat wartości. Również od Schelera Stein przejmuje rozumienie wartości jako przedmiotów intencjonalnych uczuć. Notabene, jest to pogląd zgodny z ustaleniami Brentany. W każdym razie, Stein kwestionuje stanowisko Schelera w tym zakresie, że dopuszcza ono istnienie indywiduum psychofizycznego, które nie byłoby osobą ${ }^{31}$. Innymi słowy, Stein zarzuca Schelerowi psychologizm. „Podwójną” intencjonalność opisaną przez Schelera, jako „fałszywe współczucie”, da się lepiej przedstawić za sprawą Steinowskiej koncepcji dwóch współbieżnych dynamik, a mianowicie przyczynowości psychicznej oraz motywacji. Stein oferuje w tym względzie szersze ramy interpretacyjne. Pisze: „Zamiast podzielać usłyszany sąd na podstawie własnego wglądu, mogę go przejąć »na ślepo«, napełnić się przekonaniem, nie żywiąc go »z samej siebie«. Podobnie, mogę zostać zarażona gniewem i oburzeniem, miłością i nienawiścią mojego otoczenia, odczuwać je, mimo iż nie wypływają one $\mathrm{z}$ mojego osobistego Ja"32.

Stein rozumie „fałszywe uczucia” jako wpływ otoczenia. Jej zdaniem, są one podstawą formacji „fałszywego charakteru” za sprawą intencjonalnego odniesienia do anty-wartości. Ponieważ jednak nie wywodzą się one z centrum osobowego „wykazują osobliwą pustkę i kruchość”33. Nie wytrzymują próby życiowej. Stein wyjaśnia: „Pomyślmy na przykład o wpojonej »moralności« jakiegoś człowieka, który wcale nie ma własnego kodeksu moralnego - któremu całkowicie brak, jak powiedzielibyśmy, osobistego poziomu odpowiadającego wartościom moralnym - lub o wpojonej pobożności pewnej w gruncie rzeczy osoby niewierzacej. Mogą one zostać zdemaskowane i unicestwione, przez to, że odpowiedni poziom osobisty dojdzie do głosu, ewentualnie jego brak wyjdzie na jaw (na przykład, kiedy

31 Tamże

32 E. Stein, dz. cyt., 421.

33 E. Stein, dz. cyt., 422. 
człowiek »moralny« zawodzi, gdy jest poddany próbie). Może się jednak również zdarzyć, że fałszywy charakter utrzymuje się, ponieważ autentycznym skłonnościom charakteru brakuje dogodnych warunków rozwoju lub ponieważ indywiduum psychiczne nie »żyje z własnej duszy" "34.

Pojęcie „duszy”, jakim się posługuje Stein, winno być w tym przypadku rozumiane filozoficznie, to znaczy jako jedność osobowa, czyli dusza u Platona, oraz jako forma kształtująca organizm, w ujęciu Arystotelesa. Ale jak zauważa Terrence C. Wright, szczególnym rysem Steinowskiej antropologii jest postulat dwóch form ${ }^{35}$. Chodzi nie tylko o animal rationale, czyli prototyp człowieka, ale również formę indywidualną, czyli autentyczną unikalność, to co wyróżnia „Sokratesa jako Sokratesa”. Innymi słowy, chodzi o dwojakie rozumienie duszy (psyché), a w konsekwencji dwojakie ujęcie jedności: ludzki sposób bycia oraz osobisty, autentyczny charakter. Ponadto, za sprawą świata wartości, Stein postuluje jedność osobową nie tylko w wymiarze indywiduum, ale również jako osobowość ponadindywidualną, czyli wspólnotę.

Stein, podobnie jak Scheler, ujmuje sferę emocjonalną w jej własnej specyfice, czyli logice serca, niedostępnej sądom ${ }^{36}$. Wyjaśnia: „W odróżnieniu od aktów logicznych trzeba podkreślić, że zmysłowość pełni tu zupełnie inną rolę. Nie tylko jest zakładana jako składnik przeżyć fundujących, lecz ufundowane akty same wymagają własnego »materiału«" 37 . W ramach przeżyć (Erlebnisse),

34 Tamże.

35 T.C. Wright, Artistic truth and the true self in Edith Stein, American Catholic Philosophical Quarterly 82 (2008), 132.

36 Rozróżnienie to kojarzone jest z dictum Pascala o racjach serca. Pascal utrzymuje: „Poznajemy prawdę nie tylko rozumem, ale i sercem (...) Zasady czujemy, twierdzenia wyprowadzamy za pomocą dowodu; i jedno i drugie pewnie, mimo że odmiennymi drogami." B. Pascal, Myśli, tłum. z fr. T. Boy-Żeleński, Kraków 1983, 189-190. Niemniej, właściwe ramy tego poglądu wyznaczone są przez dyskusję matematyków. Pascal uważa bowiem, że to, co poznajemy sercem, to: przestrzeń, czas, ruch i liczba. Tamże, 190.

37 E. Stein, dz. cyt., 289. 
czyli świadomie przeżywanych treści, Stein wyróżnia przeżycia „obce Ja” (ichfremde) oraz „pokrewne Ja” (ichliche). Pierwsze odnoszą się do percepcji, a właściwie apercepcji za sprawą intencjonalności, drugie natomiast związane są właśnie z czuciem. Stein pisze: „Pod nazwą »odczucie« względnie »uczucie« ujęte są dwie rzeczy: po pierwsze, akty, w których wartości względnie przedmioty jako wartościowe ukazują się nam jako »dobra«, a ponadto postawy, jakie te wartości w nas wywołują"38. Wartości jako przeżywane ,jakości”, zdaniem Stein, „wysuwają roszczenia”, czyli domagają się „odkrycia” i aprobaty. Stein wyjaśnia: „Całkowicie zrealizowane uchwycenie wartości jest więc zawsze odczuciem, w którym połączona jest intencja wartości i reakcja odpowiedzi. Tam, gdzie brakuje żywego uczestnictwa »Ja«, tam jest ono zastąpione przez nieurzeczywistnioną intencję" ${ }^{39}$. Jak w przypadku pojmowania ma miejsce wgląd i konstatacja, tak „odkrycie” wartości wyraża się jako „żywe uczestnictwo”, czyli emocja lub wzruszenie.

Rozumienie przez Stein „postaw” jako odpowiedzi na świat wartości oraz ujęcie autentycznej osobowości jako ufundowanej na „prawdziwych uczuciach” umożliwia osobową wykładnię Husserlowskiej koncepcji „cielesnej samo-obecności”. Dla Husserla oznacza ona „doświadczenie bezpośrednie”, ograniczone jednak do percepcji. Natomiast, pojęcie „cielesności” w Steinowskim ujęciu jest „ciałem żywym”. R. Ingarden pisząc o badaniach E. Stein podkreśla: „Nie o to chodzi, że jest różnica między żywym [ciałem] a martwym; ale że w tym drugim przypadku wszystko można tylko oglądać z zewnątrz (...) a nie można mieć tego całego doświadczenia, które ja mam z siebie, ze swego ciała, póki jestem żywy, kiedy jakby mieszkam w swoim ciele, mogę być wszędzie obecny jakoś w częściach mego ciała i je doznawać w rozmaity sposób” 40 . Steinowska koncepcja rozumienia,

38 Tamże, 290.

39 Tamże, 292.

40 R. Ingarden, O badanich filozoficznych E. Stein, Znak 202(1971)4, 406-407. 
jaka stąd wynika, nie ma zatem charakteru „wglądu” w uczucia, ale kształtowania postaw i charakteru jako owocu „wyczucia"41 tego, co słuszne, odpowiednie, właściwe w świetle wartości.

Stein pisze, że pierwotną tendencją w człowieku jest dążenie do jedności ${ }^{42}$, czyli kształtowanie osobowości indywidualnej, ale też budowanie osobowości ponadindywidualnej jako wspólnoty. $\mathrm{Na}$ czym jednak miałaby polegać taka jedność? Stein opisuje tę jedność na przykładzie smutku oddziału po stracie dowódcy jako zróżnicowane, żywe uczestnictwo w uczuciu, które jest wyrazem należnego szacunku i czci wobec autorytetu. Autorytet jest przy tym rozumiany jako nosiciel wartości, którymi żyją pozostałe osoby. Gdyby w imieniu oddziału nikt nie przeżywał smutku po takiej stracie, należałoby mówić o braku wspólnoty. Stanowisko Stein różni się w tym względzie z wynikami Schelera. Scheler bowiem neguje możliwość tak rozumianej osobowości, kładąc nacisk na indywidualne zróżnicowanie odczuć.

Nie ma, zdaniem Schelera, możliwości wspólnych uczuć. Stein podziela zastrzeżenia, niemniej przezwycięża tę trudność na gruncie fenomenologicznej analizy ,istoty uczucia” ${ }^{43}$. Tak, jak możliwa jest bowiem we wspólnocie badawczej różnica zdań, która pozwala wyartykułować i dookreślić wspólny przedmiot badania jako „istotę rzeczy", a nie ich wielość. Podobnie, uważa Stein, jedna i ta sama wartość, którą daje się uchwycić jako „istotę uczucia” jednoczy, dając podstawę odczuciu więzi wspólnotowej. Ponadto, wspólnota taka, podkreśla Stein, wykracza poza aktualny krąg osób, poszerzając jej widoczne granice i staje się tradycją.

41 Por. P. Janik, Hermeneutyczno-fenomenologiczne ujęcie (wy)czucia duchowego, w: Szkice z fenomenologii duchowości: od duchowości fenomenologii do fenomenalności duchowości, red. M. Kozak, R. Grzywacz, Warszawa 2019, 115.

42 Por. E. Stein, dz. cyt., 457.

43 Por. tamże, 262. 


\section{W STRONĘ SENSU TOŻSAMOŚCI INDYWIDUALNEJ}

Autentyczna osobowość wyraża się osobistą niepowtarzalnością lub oryginalnością. Stein opisuje ją jako „rdzeń osobowy”44. Jest ona całokształtem, niepodzielną całością. W tym przypadku, „silna osobowość" oznacza wyraźnie ukształtowaną charakterystykę indywidualną ${ }^{45}$, która jest zdolna przeciwstawić się wpływom zewnętrznym, a także potrafi rozpoznać to, co służy rozwojowi. Stein pisze: „Należy podkreślić, że możliwości te istnieją nie dla każdego psychicznego indywiduum, ale tylko dla osób w pełnym tego słowa znaczeniu. Istnieje w nich wolność woli względem »wpływu otoczenia«, podobnie jak wobec »naturalnej skłonności«, a »odpowiedzialności« nie można uchylić, powołując się ani jedną, ani na drugą"46. Tylko w przypadku osoby można więc sensownie mówić o indywidualnej tożsamości ${ }^{47}$.

Zdaniem Stein, rozumienie „istoty uczuć, czyli rozpoznanie sensu uczuć, to przede wszystkim uchwycenie odpowiadających im wartości lub antywartości, które oddziałują dochodząc do głosu poprzez emocje. Wartości są racjami motywującymi określone postawy. Uchwycenie ich ma się dokonywać na gruncie uczuć, dlatego mowa jest o „w-czuciu”, przez analogię do „wglądu”. Ale czy w tym przypadku analogia ta jest do utrzymania?

Opracowana przez T. Lippsa koncepcja „wczucia” (Einfuehlung) została przełożona na język angielski wraz z jego pracami w zakresie psychologiczno-estetycznym, a sam termin Einfuehlung przetłumaczony literalnie jako empathy. Stein, komentując ten pogląd, zwraca uwagę na dwie zasadnicze trudności z nim związane, przy czym obie trudności są niejako przypadkami granicznymi fenomenu „zarażenia”.

44 Por. tamże, 210, 213-217, 239. Por. P.J. Schulz, Toward the Subjectivity of the Human Person: Edith Stein's Contribution to the Theory of Identity, American Catholic Philosophical Quarterly 82 (2008).

45 Por. E. Stein, dz. cyt., 423.

46 Tamże, 424.

47 Por. tamże, 468-469. 
Pierwsza trudność to problem „siły oddziaływania”. Wydaje się bowiem, że fenomen „naśladownictwa” da się wyjaśnić przez argument „siły afektywnej”. Jeśli tak, to postuluje się jakąś „siłę psychiczną” zdolną „narzucić się" lub wywołać lęk i podporządkowanie. Stein odrzuca to wyjaśnienie. Jej zdaniem, chodzi raczej o to, że znajomość motywów nie wystarcza, jeśli w grę wchodzi oddziaływanie psychiczne. Nie jest to więc przypadek za argumentem istnienia takiej siły afektywnej, ale dotyczy „żywszego odczuwania”48. Uwzględnienie specyfiki przyczynowości psychicznej, ukazuje możliwość wpływu zarówno zewnętrznego, jak i wewnętrznej kondycji, choćby w przypadku zmęczenia. Stein wyjaśnia: „»Racjonalnie rzecz biorąc«, siła przekonania wzrasta wraz z jego właściwym uzasadnieniem, podczas gdy jego żywość może rosnąć niezależnie od tego. Możliwe jest wszelako, że żywość zostanie wzięta błędnie za siłę i ze swej strony przyczyni się do wzmocnienia przekonania"49.

Druga trudność, to problem naśladowania fenomenów ekspresji, na przykład podążania za ruchami akrobaty, czy ogólniej zachowywania się jak inni lub też udzielania się nastroju ${ }^{50}$. Przypadek ten nie jest w każdym razie jednolity. Stein rozróżnia zasadniczo: „zarażenie psychiczne” jako poddanie się „klimatowi” uczuciowemu, prowadzące do panicznego, to znaczy chaotycznego zachowania oraz rozumienie fenomenów ekspresji, które jest niezależne, choć nie wyklucza zarażenia ${ }^{51}$.

Stanowisko Lippsa krytykował też Scheler. Jego zdaniem, „wczuwanie" jest sposobem na rozumienie własnego doświadczenia za sprawą identyfikacji z bohaterem, czyli wzorcem. Według Schelera kierunek ,wczucia” jest jednak przeciwny, niż uważał Lipps, a „wczucie" polega na przypisywaniu sobie uczuć bohatera, na przykład

\footnotetext{
48 Por. tamże, 399.

49 Tamże, 400.

50 Por. tamże, 319-323.

51 Por. tamże, 323.
} 
powieści lub filmu. Innymi słowy, nazywanie czegokolwiek wymaga i zakłada język. Scheler słusznie też podkreśla, że na gruncie uczuć nie jest możliwa reprezentacja ${ }^{52}$.

Steinowskie stanowisko uwzględnia rolę języka właśnie za sprawą świata wartości. Rozumie go ona bowiem jako świat ludzkich wytworów, czyli świat kultury w szerokim tego słowa znaczeniu. W każdym człowieku daje się też rozpoznać pierwotna tendencja ku jedności i tylko wtórnie jest ona hamowana, na przykład za sprawą niesprzyjających warunków dla rozwoju ${ }^{53}$. Ale jedność w postaci tożsamości nie usuwa samotności indywiduum. Stein pisze: „Duch jest wyjściem poza siebie samego, otwartością w dwojakim sensie: na świat przedmiotów, który jest doświadczany, i na obcą podmiotowość, obcego ducha, z którym razem będzie doświadczany i przeżywany. (...) Otwartość w innym sensie usuwa jednak izolację jednostki, wstawia ją w kontekst świata duchowego. (...) Ponieważ ta otwartość należy do pierwotnej postawy życiowej duchowej jednostki, można ze słusznością powiedzieć, że posiada ona pierwotnie istotę zarówno społeczną, jak i indywidualną; nie unieważnia to przecież faktu, że twory społeczne mają podstawę w jednostkach" ${ }^{54}$.

Sens tożsamości indywidualnej nie jest zatem czymś do osiągania, lecz jest drogą, procesem, który zna zarówno kryzys, jak i cezurę, czyli moment jego przezwyciężenia, który daje się zwerbalizować jako „urzeczywistniona wartość”.

\section{ZAKOŃCZENIE}

Steinowska koncepcja rozumienia uczuć ma niewiele wspólnego z poznawaniem, to znaczy ujmowaniem sensu ideału, który w jakościach

52 Por. M. Scheler, Die Idole der Selbsterkenntnis, w: tenże, Vom Umsturz der Werte, Gesammelte Werke III, Bern 1972, 265-266.

53 Por. E. Stein, dz. cyt., 457.

54 Tamże. 
uczuć odzwierciedla urzeczywistnione wartości. Nie chodzi zatem o wczucie, jako literalny odpowiednik wglądu. Rozumienie uczuć nie dotyczy znaczeń, czyli treści pojęć, choć znajduje analogię w koncepcji dialogu i dyskursu. Rozumienie drugiego człowieka nie jest jednorazowym aktem, ale raczej komunikacją, procesem. Jest ruchem i życiem, wymianą i wzajemnym odnoszeniem do drugiego człowieka, czyli swoistą diapatia.

Historyczny charakter tego rozumienia, odrzucony w nietzscheańskim żądaniu przewartościowania wszystkich wartości, nie oznacza względności sensu komunikowanego za sprawą uczuć. Przeciwnie, sens ten jest dostępny we wspólnocie, połączonej więzami osobowymi, wspólnocie, która jako tradycja przekracza ramy czasu. I podobnie w odniesieniu do indywiduum, ów sens jest ugruntowaniem wiedzy jako wiedzy dzielonej (syneidesis, conscientia), to znaczy świadomości lub sumienia.

Fenomenologia francuska za sprawą M. Merleau-Ponty'ego oraz R. Barbarasa podejmie ten kierunek badań, odsłaniając słuszność wypracowanych przez E. Stein ustaleń. Dodać wypada, że Steinowska koncepcja nie traci na aktualności, choć trzeba przyznać, że zasługuje na szersze zainteresowanie i pogłębione badania.

\section{BIBLIOGRAFIA}

Brentano F., Psychologia z empirycznego punktu widzenia, tłum. z niem. W. Galewicz, PWN, Warszawa 1999.

Heidegger M., Bycie i czas, tłum. z niem. B. Baran, PWN, Warszawa 1994.

Husserl E., Idee czystej fenomenologii ifenomenologicznej filozofii, ks. 1, thum. z niem. D. Gierulanka, PWN, Warszawa² 1975.

Ingarden R., O badaniach filozoficznych E. Stein, Znak 202(1971)4, 389-409.

Janik P., „Czynności $i$ wytwory” w perspektywie fenomenologicznej, Filo-Sofija 40(2018)1, 151-162.

Janik P., Hermeneutyczno-fenomenologiczne ujęcie (wy)czucia duchowego, w: Szkice $z$ fenomenologii duchowości: od duchowości fenomenologii do fenomenalności 
duchowości, red. M. Kozak, R. Grzywacz, Wyd. IFiS PAN, Warszawa 2019, 109-122.

Lebech M., Edith Stein's Phenomenological Value Theory, Yearbook of the Irish Philosophical Society (2010), 139-150.

Pascal B., Myśli, tłum. z fr. T. Boy-Żeleński, PAX, Kraków 1983.

Scheler M., Die Idole der Selbsterkenntnis, w: tenże, Vom Umsturz der Werte, Gesammelte Werke III, Francke, Bern 1972, 213-292.

Scheler M., Istota i formy sympatii, tłum. z niem. A. Węgrzecki, PWN, Warszawa 1980.

Scheler M., Der Formalismus in der Ethik und die materiale Wertetbik: neuer Versuch der Grundlegung eines ethischen Personalismus, red. M.S. Frings, Bouvier, Bonn 2009.

Schulz P.J., Toward the Subjectivity of the Human Person: Edith Stein's Contribution to the Theory of Identity, American Catholic Philosophical Quarterly 82(2008), 161-176.

Stein E., Filozofia psychologii i humanistyki, tłum. z niem. P. Janik, M. Baran, J. Gaca, Wydawnictwo Karmelitów Bosych, Kraków 2016.

Wright T.C., Artistic truth and the true self in Edith Stein, American Catholic Philosophical Quarterly 82(2008), 127-142.

\section{THE SIGNIFICANCE OF FEELINGS. STEIN'S LEGACY}

Abstract. Stein's theory of empathy lies at the intersection of the phenomenological findings of E. Husserl and M. Scheler. By presenting the issue of "empathy" in a broader framework, including intentionality, the originality of experience, the issue of personality and the individual identity, as well as the so-called world of values, namely the culture, I argue for a dynamic, process-oriented concept of dealing with feelings, namely diapathy.

Keywords: Phenomenology, Anthropology, feelings, empathy, values, E. Stein, F. Brentano, E. Husserl, M. Scheler

\footnotetext{
PIOTR JANIK

piotr.janik@ignatianum.edu.pl

Akademia Ignatianum w Krakowie, Instytut Filozofii

ul. Kopernika 26, 31-501 Kraków

ORCID: 0000-0001-6528-0996
}

DOI: 10.21697/spch.2020.56.2.05 